\title{
TEXTURAL CHARACTERISTICS OF COMPOSITE ADSORBENTS ANALYZED WITH DENSITY FUNCTIONAL THEORY AND SELF-CONSISTENT REGULARIZATION PROCEDURE
}

\author{
Chuiko Institute of Surface Chemistry of National Academy of Sciences of Ukraine \\ 17 General Naumov Str., Kyiv, 03164, Ukraine,E-mail:vlad_gunko@ukr.net
}

\begin{abstract}
Highly disperse or porous complex and hybrid materials and nanocomposites characterized by the presence of several phases, nonuniform particulate morphology, and complicated porosity with contributions of pores of various shapes are widely used in various applications in industry and medicine. Accurate determination of their textural characteristics is of importance from a practical point of view because these characteristics play an important role in practically all applications of the materials. The aim of this study, to solve the mentioned task, is to develop a selfconsistent regularization (SCR) procedure applied to integral adsorption equations based on complex models with slit-shaped and cylindrical pores and voids between spherical particles packed in random aggregates (SCV model) for two or three types of components (such as activated carbon, carbon black, silica gel, and fumed silica) in composites, mechanically treated, with application of the density functional theory (DFT) method. The pore size distribution (PSD) functions calculated using the DFT SCVISCR method are compared to the PSD calculated for the same materials with the SCV/SCR method based on the modified BET/Kelvin equations (MND method) previously developed. The DFT SCVISCR method works better than the latter since it gives smaller model errors and better describes the PSD functions of composite components alone. The DFT SCV/SCR method could be used to study the textural characteristics of various complex and hybrid materials and composites which are characterized by a nonuniform porosity. It should be noted that the PSD functions of similar complex adsorbents are difficult to be calculated using standard approaches distributed with firm software due to restriction on the type of material (typically one) and the absence of SCR.
\end{abstract}

Keywords: complex adsorbents, pore size distributions, textural characteristics, binary mixtures, ternary mixtures, DFT with self-consistent regularization

\section{INTRODUCTION}

Textural characterization of complex multicomponent materials (such as carbonmineral, polymer-mineral, oxide I - oxide II/carbon I - carbon II, etc.) is not a simple task because of significant differences in surface and pore structures of components. Firm software (implemented in various adsorption analyzer equipment) based on density functional theory (DFT) $[1,2]$ includes different models of pores and matters. For example, models with slitshaped pores in carbons, cylindrical pores in silica and zeolites, 2D-discs in carbons and windows in clays (Micromeritics, http://www.micromeritics.com/) [3-11], or slit-shaped and slit/cylindrical pores in carbons and cylindrical pores in silica or zeolites (nonlocal DFT, NLDFT) and slit-shaped, cylindrical, slit/cylindrical, cylindrical/spherical and slit-shaped, cylindrical and spherical pores in carbons (quenched solid DFT, QSDFT) (Quantachrome, http://www.quantachrome.com/)
[12-17], etc. are widely used. Frequently, obsolete Barrett-Joyner-Halenda (BJH) method [18] implemented in firm software is also used despite its known disadvantages. In the firm DFT software, the complex pore models are applied only to one matter, e.g. carbon, silica, zeolite, or clay, etc. This is an obvious disadvantage upon analysis of hybrid and complex materials. There is an additional disadvantage related to the use of the mentioned complex pore models with fixed contributions of pores of different shapes into the adsorbents. Clearly, components in composites can give various contributions into the textural characteristics that can also change due to the material interactions and changes, e.g., upon preparation and storage of the materials. For example, mechanical mixing of activated carbons and mineral adsorbents, polymer filling by porous particles, attachment of nanoparticles to polymer brushes, etc. can affect the pore accessibility of each component in the composites. As a whole, if an adsorbent is composed of several different 
components (e.g., a mixture of silica and carbon adsorbents) it is difficult to assume that the mentioned pore models for one component (e.g. silica or carbon) can give an appropriate pore size distribution (PSD) for another component and, therefore, for the whole composite material. Note that there is a variety of developments [19-45] not yet implemented in the firm software which, however, can be used for more accurate description of complex and hybrid materials. In previous papers [43-45], a self-consistent regularization (SCR) procedure applied to complex models of pores in complex materials (nanosilica + silica gel + carbons (activated carbon and carbon black)) was described. This approach was based on a blend of Kelvin and modified BET equations [46-48] (MND method) that was used in the SCV/SCR method with models of slit-shaped and cylindrical pores and voids between spherical nanoparticles (SCV model) [43-45]. Note that the SCR procedure was also successfully applied to analyze the SAXS data to compute the particle size distributions with models of spherical, lamellar, and cylindrical particles [49-51]. However, the MND method has some disadvantages. Therefore, the aim of this paper was to develop the SCV/SCR approach on the basis of the DFT method and to test it using a set of nitrogen adsorption-desorption isotherms for binary (nanosilica A-200/silica gel Si-60, A-200/activated carbon (PS1), A-200/carbon black Envicarb, Si-60/Envicarb, Si-60/PS1, and PS1/Envicarb) and ternary (A-200/Si-60/Envicarb, A-200/Si-60/PS1, A-200/PS1/Envicarb, and Si-60/PS1/Envicarb) systems previously studied using the MND SCV/SCR method [43].

\section{MATERIALS AND METHODS}

To analyze the textural characteristics of complex adsorbents, four types of materials were used here: silica gel Si-60 (Merck, particles of
$0.2-0.5 \mathrm{~mm}$ in diameter), fumed silica A-200 (Pilot plant of the Chuiko Institute of Surface Chemistry, Kalush, Ukraine, primary nanoparticles of $11.7 \mathrm{~nm}$ in average diameter), activated carbon (PS1) prepared from plum stones (PSO MASKPOL, Poland, particles of $0.5-1.0 \mathrm{~mm}$ in size), and graphitized carbon black Envicarb (Supelco, Bellefonte, particles of $40-60 \mu \mathrm{m}$ in diameter). These materials as individual and complex adsorbents were described in detail elsewhere [35-43]. A set of complex adsorbents (Table 1) was prepared by mechanical mixing of individual adsorbents as $1: 1 \mathrm{w} / \mathrm{w}$ for binary systems or $1: 1: 1 \mathrm{w} / \mathrm{w} / \mathrm{w}$ for ternary systems with no strong mechanical loading in a porcelain mortar.

To analyze the textural characteristics of individual and complex materials (Table 1), lowtemperature $(77.4 \mathrm{~K})$ nitrogen adsorption/desorption isotherms (Fig. 1) were recorded using a Micromeritics ASAP 2405N adsorption analyzer or a Quantachrome Autosorb analyzer. The specific surface area $\left(S_{\mathrm{BET}}\right)$ was calculated according to the standard BET method [52]. The total pore volume $V_{\mathrm{p}}$ was evaluated from the nitrogen adsorption at $p / p_{0} \approx 0.99$ ( $p$ and $p_{0}$ denote the equilibrium and saturation pressure of nitrogen at $77.4 \mathrm{~K}$, respectively) [53].

The Steele potential $[46,47]$ was used to calculate the nitrogen adsorption in slit-shaped pores

$$
\begin{aligned}
& U(x, y)=\varphi(y)+\varphi(x-y), \\
& \varphi(y)=4 \pi \rho_{s} \sigma_{s f}^{2} \varepsilon_{s f} \Delta\left[0,2\left(\frac{\sigma_{s f}}{y}\right)^{10}-0,5\left(\frac{\sigma_{s f}}{y}\right)^{4}-\frac{\sigma_{s f}^{4}}{6 \Delta(y+0,61 \Delta)^{3}}\right],
\end{aligned}
$$

where $\Delta=0.3354 \mathrm{~nm}$ is the thickness of a monomolecular nitrogen layer, and $y$ is the distance to the plane.

The solid-fluid interaction in cylindrical pores was determined by equation [54]

$U(r, R)=\pi^{2} \rho_{s} \varepsilon_{s f} \sigma_{s f}^{2}\left[\frac{63}{32}\left[\frac{r}{\sigma_{s f}}\left(2-\frac{r}{R}\right)\right]^{-10} F\left[-4.5,-4.5,1,\left(1-\frac{r}{R}\right)^{2}\right]-\left[3\left[\frac{r}{\sigma_{s f}}\left(2-\frac{r}{R}\right)\right]^{-4} F\left[-1.5,-1.5,1,\left(1-\frac{r}{R}\right)^{2}\right]\right.\right.$

where $\mathrm{F}[\alpha, \beta, \gamma, \chi]$ is the hypergeometric series, $r$ is the radial coordinate, $\varepsilon_{\mathrm{sf}}$ is the surface-fluid parameter in the Lennard-Jones potential, $\sigma_{\mathrm{sf}}=\left(\sigma_{\mathrm{s}}+\sigma_{\mathrm{f}}\right) / 2$ is the average collision diameter of surface and fluid atoms; and $\rho_{\mathrm{s}}$ is the density of surface (e.g., carbon or oxygen) atoms.

The PSD functions were calculated using overall equation (with the framework of DFT) $[55,56]$ 
Table 1. Textural characteristics of individual adsorbents and their binary $(1: 1 \mathrm{w} / \mathrm{w})$ and ternary $(1: 1: 1 \mathrm{w} / \mathrm{w}) \mathrm{mixtures}(\mathrm{DFT} \mathrm{SCV} / \mathrm{SCR})$

\begin{tabular}{|c|c|c|c|c|c|c|c|c|c|c|c|c|c|c|}
\hline Adsorbent & $\begin{array}{l}S_{\text {BET, }} \\
\mathrm{m}^{2} / \mathrm{g}\end{array}$ & $\begin{array}{c}S_{\text {BET,ad, }} \\
\mathbf{m}^{2} / \mathbf{g}\end{array}$ & $\Delta w$ SCR,MND & $\Delta w \mathrm{SCR}, \mathrm{DFT}$ & $\begin{array}{c}V_{\mathrm{p}}, \\
\mathrm{cm}^{3} / \mathrm{g}\end{array}$ & $\begin{array}{c}V_{\mathrm{p}, \mathrm{ad}}, \\
\mathrm{cm}^{3} / \mathrm{g}\end{array}$ & $\begin{array}{l}V_{\text {nano, }} \\
\mathrm{cm}^{3} / \mathrm{g}\end{array}$ & $\begin{array}{l}V_{\text {meso, }} \\
\mathrm{cm}^{3} / \mathrm{g}\end{array}$ & $\begin{array}{l}V_{\text {macro, }}, \\
\mathrm{cm}^{3} / \mathrm{g}\end{array}$ & $\begin{array}{c}S_{\text {nanoo }} \\
\mathbf{m}^{2} / \mathrm{g}\end{array}$ & $\begin{array}{c}S_{\text {meso }} \\
\mathrm{m}^{2} / \mathrm{g}\end{array}$ & $\begin{array}{c}S_{\text {macro, }}, \\
\mathbf{m}^{2} / \mathbf{g}\end{array}$ & $\begin{array}{c}<\boldsymbol{R}_{\mathrm{V}}> \\
\mathbf{n m}\end{array}$ & $\begin{array}{c}<\boldsymbol{R}_{\mathrm{S}}> \\
\mathbf{n m}\end{array}$ \\
\hline A-200 & 233 & & & & 0.557 & & 0 & 0.269 & 0.288 & 0 & 202 & 31 & 25.5 & 9.9 \\
\hline Si-60 & 456 & & & & 0.822 & & 0.076 & 0.746 & 0 & 123 & 333 & 0 & 3.2 & 2.3 \\
\hline PS1 & 810 & & & & 0.447 & & 0.386 & 0.060 & 0.001 & 774 & 37 & 0 & 0.98 & 0.62 \\
\hline Envicarb & 99 & & & & 0.753 & & 0.041 & 0.615 & 0.097 & 46 & 51 & 2 & 15.8 & 5.0 \\
\hline A-200/Si-60 & 376 & 344 & 0.194 & 0.097 & 0.798 & 0.690 & 0.145 & 0.579 & 0.075 & 196 & 177 & 2 & 8.0 & 1.9 \\
\hline A-200/PS1 & 699 & 522 & 0.267 & 0.275 & 0.530 & 0.502 & 0.283 & 0.197 & 0.050 & 614 & 83 & 2 & 7.5 & 0.97 \\
\hline A-200/Envicarb & 160 & 166 & 0.151 & 0.045 & 0.564 & 0.655 & 0.062 & 0.426 & 0.076 & 90 & 68 & 2 & 15.0 & 3.4 \\
\hline Si-60/PS1 & 629 & 633 & 0.124 & 0.051 & 0.645 & 0.635 & 0.266 & 0.368 & 0.011 & 463 & 166 & 0.2 & 3.2 & 1.1 \\
\hline Si-60/Envicarb & 277 & 278 & 0.255 & 0.149 & 0.857 & 0.788 & 0.059 & 0.418 & 0.380 & 116 & 145 & 17 & 21.0 & 4.9 \\
\hline Envicarb/PS1 & 462 & 455 & 0.149 & 0.121 & 0.620 & 0.600 & 0.145 & 0.250 & 0.225 & 399 & 51 & 11 & 21.8 & 2.2 \\
\hline A-200/Si-60/PS1 & 540 & 500 & 0.255 & 0.036 & 0.623 & 0.609 & 0.229 & 0.362 & 0.032 & 394 & 145 & 1 & 5.1 & 1.2 \\
\hline A-200/Si-60/Envicarb & 254 & 263 & 0.147 & 0.033 & 0.667 & 0.711 & 0.094 & 0.476 & 0.097 & 132 & 120 & 2 & 14.9 & 2.5 \\
\hline A-200/PS1/Envicarb & 405 & 381 & 0.328 & 0.281 & 0.546 & 0.586 & 0.137 & 0.315 & 0.094 & 306 & 94 & 4 & 13.5 & 1.8 \\
\hline Si-60/PS1/Envicarb & 487 & 455 & 0.212 & 0.111 & 0.707 & 0.674 & 0.195 & 0.442 & 0.070 & 351 & 133 & 3 & 9.6 & 1.6 \\
\hline
\end{tabular}

Note. The $V_{\text {nano }}$ and $S_{\text {nano }}$ values were calculated by integration of the $f_{\mathrm{V}}(R)$ and $f_{\mathrm{S}}(R)$ function, respectively, at $0.35 \mathrm{~nm}<R<1 \mathrm{~nm}, V_{\text {meso }}$ and $S_{\text {meso }}$ at $1 \mathrm{~nm}<R<25 \mathrm{~nm}$, and $V_{\text {macro }}$ and $S_{\text {macro }}$ at $25 \mathrm{~nm}<R<100 \mathrm{~nm}$. Additive values $S_{\mathrm{BET}, \text { ad }}=\sum_{\mathrm{i}} S_{\mathrm{BET}, \mathrm{i}} / \mathrm{n}$ and $V_{\mathrm{p}, \text { ad }}=\sum_{\mathrm{i}} V_{\mathrm{p}, \mathrm{i}} / n$, where $n$ is the number of components. $\Delta w_{\mathrm{SCR}, \mathrm{MND}}$ and $\Delta w_{\mathrm{SCR}, \mathrm{DFT}}$ are the model errors (see Eq. (12)) for MND SCV/SCR and DFT SCV/SCR methods. The values of $<R_{\mathrm{V}}>$ and $<R_{\mathrm{S}}>$ correspond to the first moments of the distribution functions $<R_{X}>=\int_{R_{\min }}^{R_{\max }} R f_{X}(R) d R / \int_{R_{\min }}^{R_{\max }} f_{X}(R) d R$ with respect to the pore volume $(\mathrm{X}=\mathrm{V})$ and specific surface area $(\mathrm{X}=\mathrm{S})$ 
$W(p)=v_{M}\left[\int_{\sigma_{s s} / 2}^{r_{k}(p)} \rho_{f}(R) f(R) d R+\int_{r_{k}(p)}^{R_{\max }} \frac{t}{R-\sigma_{s s} / 2} \rho_{M}(R) f(R) d R\right]$

where $W$ is the adsorption, where $v_{\mathrm{M}}$ the liquid molar volume, $\rho_{\mathrm{f}}$ the fluid density in occupied pores, $\rho_{\mathrm{m}}$ the density of the multi-layered adsorbate in pores, $r_{\mathrm{k}}$ the radius of pores occupied at the pressure $p, \sigma_{\mathrm{ss}}$ is the collision diameter of the surface atoms. To calculate the density of a gaseous adsorbate (nitrogen) at a given pressure $p$, Bender equation [57] was used

$p=\rho T\left[R_{g}+B \rho+C \rho^{2}+D \rho^{3}+E \rho^{4}+F \rho^{5}+\left(G+H \rho^{2}\right) \rho^{2} \exp \left(-a_{20} \rho^{2}\right)\right]$,

where $B=a_{1}-a_{2} / T-a_{3} / T^{2}-a_{4} / T^{3}-a_{5} / T^{4} ; C=a_{6}+a_{7} / T+a_{8} / T^{2} ; D=a_{9}+a_{10} / T ; E=a_{11}+a_{12} / T ; F=a_{13} / T$; $G=a_{14} / T^{3}+a_{15} / T^{4}+a_{16} / T^{5} ; H=a_{17} / T^{3}+a_{18} / T^{4}+a_{19} / T^{5} ; a_{20}=\rho_{c}^{-2} ; a_{i}$ are constants, and $R_{\mathrm{g}}$ is the gas constant. Transition from gas (subscript $g$ ) to liquid $(l)$ or fluid in the form of multi-layered adsorbate in pores $(m)$ can be linked to the corresponding fugacity $f$

$\ln \frac{f(T, \rho)}{R_{g} T \rho}=\frac{p(T, \rho)}{R_{g} T \rho}-1+\frac{1}{R_{g} T} \int_{0}^{\rho}\left[p(T, \rho)-R_{g} T \rho\right] \frac{d \rho}{\rho^{2}}$

and

$f_{l, m}=f_{g} \exp \left(\frac{E_{i, m}}{R T}\right)$

where $E$ is the interaction energy of an adsorbate molecule with the pore walls and neighboring molecules calculated with the LD potentials.

The integral adsorption equation may be written as a sum of several equation (4) for various components of complex adsorbents with different pore size distribution functions describing pores of different shapes [43-45]

$$
A_{\Sigma}(p)=\sum_{j} c_{j} W_{j}(p)
$$

where $W_{j}(\mathrm{p})$ is the adsorption into j-type of pores, $c_{j}=c_{\text {slit }}, c_{c y l}$, and $c_{\text {void }}$ are the weight constants $\left(c_{s l i t}+c_{c y l}+c_{\text {void }}=1\right)$ determining contributions of slit-shaped and cylindrical pores and voids between spherical particles to the volume filled by adsorbate under pressure $p\left(A_{\Sigma}(p)\right) ; r_{k, j}$ is the halfwidth of slit pores, the radius of cylindrical pores or meniscus radius for voids.

Equation (8) can be solved using selfconsistent regularization (based on CONTIN algorithm [58]) with respect to slit-shaped and cylindrical pores and voids between spherical particles (model SCV) with fixed regularization parameter $(0.01$ or 0.001$)$. The $c_{\mathrm{j}}$ values were determined under condition of the best fitting of an experimental isotherm $\left(A_{\exp }(p)\right)$ by a combined isotherm determined by Eq. (8) using minimization of the functional

$$
\begin{aligned}
& \Psi\left(c_{j}\right)=\int_{p_{\min }}^{p_{\max }} p^{-1}\left[A_{\text {exp }}(p)-\sum_{j} c_{j} W_{j}(p)\right]^{2} d p \rightarrow \text { minimum } \\
& \text { at } \frac{d \Psi\left(c_{j}\right)}{d c_{j}}=0 \text { and } \mathrm{j}=1,2,3,
\end{aligned}
$$

where $p_{\min }$ and $p_{\max }$ are minimal and maximal pressures of nitrogen for recorded isotherm. The initial $c_{\text {slit }, 0}, c_{c y l, 0}$, and $c_{\text {void, }, 0}$ values can be estimated from known morphology of a complex materials. If this morphology is unknown that it is possible to assume the initial condition $c_{\text {slit },}=c_{c y l, 0}=c_{\text {void }, 0}=1 / 3$. According to the $c_{\text {slit }, 0}$, $c_{c y l, 0}$, and $c_{\text {void, }, 0}$ values, the corresponding portions of the adsorption isotherm are determined and three integral adsorption equations of a type (8) for different pore models and different materials can be solved using the SCR procedure. The next step is the minimization of the functional as described in Eq. (9). Then calculated new $c_{\text {sliti, }}$, $c_{c y l, i}$, and $c_{v o i d, I}$ values are used in a new partition of the isotherms and a new regularization step 
starts. Typically, $8-10$ iterations in the regularization/functional minimization are enough to obtain the self-consistent solution. Notice, that each pore model can be used for different materials that allows the calculations of the PSD for composite materials with different components characterized by different pore shapes. The DFT SCV/SCR procedure differs from the standard DFT methods implemented in firm software in respect to (i) the possibility of simultaneous use of several types of the pore models for different materials and (ii) unfixed weight coefficients $\left(c_{j}\right)$ in the overall integral equation (8) for different types of pores in different adsorbents.

The specific surface area determined under the complex pore model $\left(S_{\text {sum }}\right)$ can be calculated from the differential pore size distributions $f_{\mathrm{S}, j}(R)$ as follows

$S_{\text {sum }}=\sum_{j} c_{j} \int_{R_{\min }}^{R_{\max }} f_{S, j}(R) d R=\sum_{j} c_{j} \int_{R_{\min }}^{R_{\max }} \frac{w_{j}}{R}\left(f_{V, j}(R)-\frac{V_{j}}{R}\right) d R$

where $R_{\min }$ and $R_{\max }$ are the minimal and maximal values of pore radius (in this paper, $R_{\min }=0.35 \mathrm{~nm}$ and $\left.R_{\max }=100 \mathrm{~nm}\right), w_{j}=1$ for ideal slit-shaped pores, $w_{j}=2$ and 3 for cylindrical and spherical pores, respectively, and $w_{j} \approx 1.36$ for a cubic lattice with nonporous spherical particles. Effective $w_{\mathrm{ef}}$ value for random aggregates with nonporous spherical particles under the SCR procedure can be estimated as follows

$w_{e f}=\frac{\int R f_{S}(R) d R}{\int f_{V}(R) d R}$.

For evaluation of deviation $(\Delta w)$ of the pore shape from the model, a parameter [59]

$$
\Delta w=\frac{S_{B E T}}{\int_{R_{\min }}^{R_{\max }} f_{S}(R) d R}-1
$$

where $R_{\max }$ and $R_{\min }$ are the maximal and minimal pore radii, respectively, may be used as a criterion of the reliability of the pore model, since $S_{B E T}$ is a conventional parameter independent on the pore shape and material type.

The differential PSDs (calculated using the SCV/SCR model) with respect to pore volume
$\left.f_{\mathrm{V}}(R) \sim \mathrm{d} V / \mathrm{d} R, \int f_{\mathrm{V}}(R) \mathrm{d} R \sim V_{\mathrm{p}}\right)$ were re-calculated to incremental PSD (IPSD, $\Phi_{\mathrm{V}}\left(R_{i}\right)=\left(f_{\mathrm{V}}\left(R_{i+1}\right)+\right.$ $\left.f_{\mathrm{V}}\left(R_{i}\right)\right)\left(R_{\mathrm{i}+1}-R_{\mathrm{i}}\right) / 2$ at $\left.\sum \Phi_{\mathrm{V}}\left(R_{i}\right)=V_{\mathrm{p}}\right)$ [43-45]. This recalculation provides better view of the PSD in the large range (from nanopores to broad mesopores and macropores) since the differential $f_{\mathrm{V}}(R)$ is much lower in the range of broad mesopores and macropores than that in the range of nanopores and narrow mesopores. The $f_{\mathrm{V}}(R)$ and $f_{\mathrm{S}}(R)$ functions were also used to calculate contributions of nanopores ( $V_{\text {nano }}$ and $S_{\text {nano }}$ at $0.35 \mathrm{~nm}<R<1 \mathrm{~nm})$, mesopores $\left(V_{\text {meso }}\right.$ and $S_{\text {meso }}$ at $1 \mathrm{~nm}<R<25 \mathrm{~nm}$ ), and macropores ( $V_{\text {macro }}$ and $S_{\text {macro }}$ at $25 \mathrm{~nm}<R<100 \mathrm{~nm}$ ) to the total pore volume and the specific surface area.

\section{RESULTS AND DISCUSSION}

It should be noted that some compositions demonstrate additivity of the values of $S_{\mathrm{BET}}$ (Table 1, $S_{\text {BET }}$ and $S_{\text {BET,ad, e.g., A-200/Envicarb, }}$ Si-60/Envicarb, Si-60/PS1, Envicarb/PS1, A-200/Si-60/Envicarb), $\quad V_{\mathrm{p}}$ and $V_{\mathrm{p}, \mathrm{ad}}, \quad$ e.g., Si-60/PS1, Envicarb/PS1), but others are characterized by certain differences in these values. The latter could be explained by, at least, three factors: (i) partial decomposition of carbon particles (especially PS1) upon interaction with more rigid silica particles during mechanical mixing; (ii) partial filling of pores by small nanoparticles or carbon particle fragments; and (iii) compaction of nano/microparticles during mechanical mixing.

To compare the PSD calculated using the DFT and MND SCV/SCR methods, two carbons (activated carbons PS1 and graphitized carbon black Envicarb) and two silicas (silica gel $\mathrm{Si}-60$ and fumed silica A-200) were selected as representative different materials with different texture. The materials are: (i) with nonporous nanoparticles (average diameter $11.7 \mathrm{~nm}$ ) forming porous aggregates $(<1 \mu \mathrm{m})$ and agglomerates of aggregates $(>1 \mu \mathrm{m})(\mathrm{A}-200)$; (ii) weakly porous microparticles of $40-60 \mu \mathrm{m}$ in diameter (Envicarb); (iii) or strongly porous globules of millimeter scale, which are mainly nanoporous (PS1) or mesoporous (Si-60). Thus, the adsorbents particles have pores of different shapes in different size ranges from nanopores (pore half-width or radius $R \leq 1 \mathrm{~nm}$ ), mesopores $(1 \mathrm{~nm}<R \leq 25 \mathrm{~nm})$ to macropores $(R>25 \mathrm{~nm})$ (Table 1). 
Simple mixing, stirring, mechanochemical activation or other treatments of complex and hybrid materials can affect the morphology, structure, and texture of components [40, 42]. Therefore, the additivity of the textural characteristics of individual materials in the complex systems can be only partial (Table $1, S$ and $V$ ). Special approaches such as DFT and MND SCV/SCR can be used for appropriate determination of the textural characteristics of complex and hybrid materials.

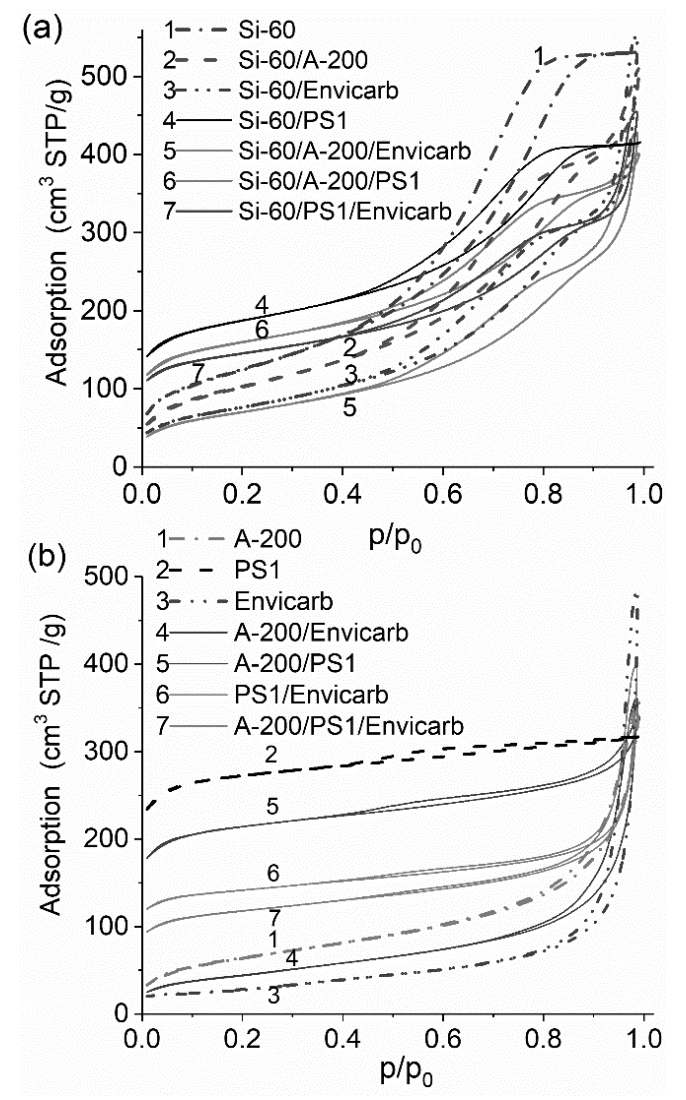

Fig. 1. Nitrogen adsorption-desorption isotherms for individual adsorbents (a) Si-60 and (b) A-200, PS1, and Envicarb, and $(a, b)$ their binary and ternary mixtures (STP - standard temperature and pressure conditions)

Nitrogen adsorption-desorption isotherms for complex materials have a complex shape (Fig. 1). Sometimes the isotherms have unusual hysteresis loops (Fig. $1 a$, curves 2-7), when pores of components (e.g., A-200 and Envicarb) are of different shapes but in close size ranges. If components have pores mainly in different size ranges (e.g. A-200 and PS1) that the nitrogen adsorption/desorption isotherms for the mixtures can have nearly standard shapes with clear contributions of different components to the sum isotherms (Fig. 1, compare the isotherms for individual adsorbents and their mixtures). The isotherm shapes suggest that pores of components in mechanical mixtures studied are accessible for nitrogen molecules since some portions of the isotherms for binary and ternary materials well correspond to those of individual components with consideration of their weight contributions to the mixtures (Fig. 1). Thus, the adsorbents blends could possess the textural characteristics roughly corresponding to weight contributions of individual components (Table 1). However, during mechanical mixing the fragments of carbon particles can cover a surface of silica particles, especially fumed silica A-200, which is composed of nonporous primary nanoparticles. Partial decomposition of carbon particles and the formation of carbon deposits on a silica surface can affect the pore volume and $S_{\mathrm{BET}}$ values of the mixtures (Table 1).

The aforementioned results can be explained by more effective decomposition of PS1 particles upon interaction with A-200 particles (during their mechanical mixing) than with much larger Si-60 or Envicarb particles. Silica and Envicarb particles are more stable than PS1 particles. Primary particles of both silicas are stable even during mechanical mixing with a grinder giving much stronger mechanical loading [40, 42]. However, secondary particles (aggregates of nanoparticles and agglomerates of aggregates) of A-200 can be easily destroyed. A partial decomposition of the PS1 particle is accompanied by opening of a portion of pores closed in the initial AC particles. This effect leads to an increase in the specific surface area of the carbon component in the mechanical mixtures (Table 1, $S_{\mathrm{BET}}$ ). In the case of silica gel $\mathrm{Si}-60$, carbon (from decomposed carbon particles) can form a partial coverage mainly at the outer surface of silica globules. A carbon layer is practically absent in intra-globular mesopores of $\mathrm{Si}-60$ (see PSD in Figs. 2 and 3); i.e., the pores in silica gel globules are not strongly blocked by carbon deposits. Therefore, the isotherms for the mixtures are not lower than that for the normalized sums of the isotherms for the corresponding components [43]. Thus, different effects of mixing of silicas and carbon adsorbents lead to a question: how the PSD of the silica/carbon mixtures should be calculated with respect to the pore models (e.g. 
slit-shaped or cylindrical models) and what material types should be considered (i.e. carbon or silica)?

For the binary systems (Table 1, Fig. 2), the DFT SCV/SCR method provides better correspondence between the PSD of the blends and the PSD of individual components (e.g. nanopores in PS1, Fig. $2 b, d, f$, or mesopores in Si-60, Fig. $2 e$ ) than that for the MND method. Certain displacements of the PSD peaks for composites could be explained by several factors (appearing during mechanical treatment of the blends) such as decomposition of soft PS1 particles, partial filling of pores by the carbon fragments, deposition of a carbon phase onto a silica surface, opening a portion of carbon pores, which were closed in the initial adsorbent, compaction of secondary structures with nanoparticles and fragments that results in a shift of PSD peak of meso/macropores toward larger pore sizes (systems with carbon black or nanosilica). As a whole, tendencies in the changes in the PSD of the blends are similar for both DFT and MND approaches. However, the model errors (Table $1, \Delta w$ ) are smaller for DFT than for MND for all systems.
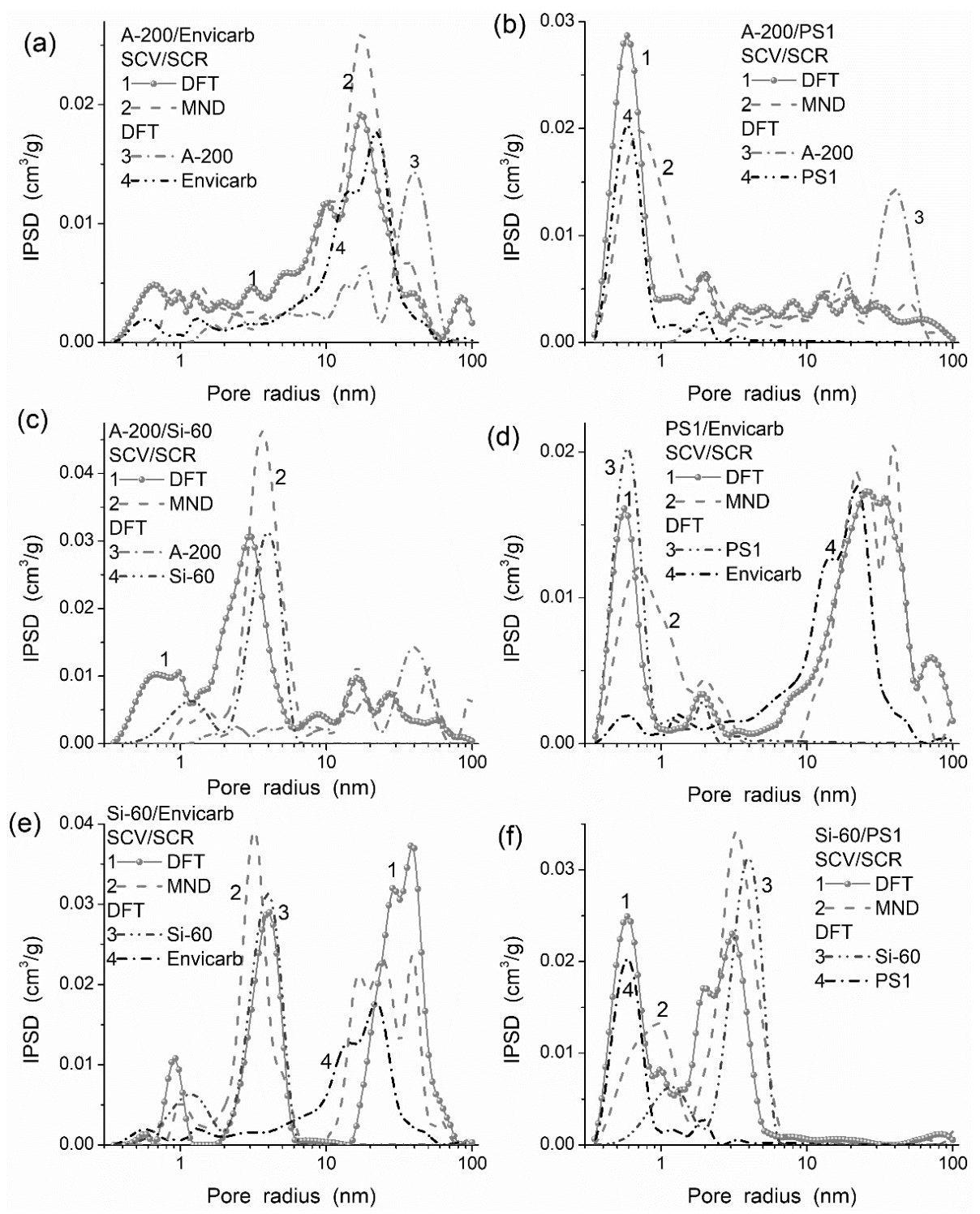

Fig. 2. Incremental PSD for binary (DFT and MND SCV/SCR PSD) and individual (DFT, multiplied by 0.5) systems (a) A-200 and Envicarb, (b) A-200 and PS1, (c) A-200 and Si-60, (d) PS1 and Envicarb, (e) Si-60 and Envicarb, and (f) Si-60 and PS1 
For the ternary systems (Table 1, Fig. 3), the results of the DFT SCV/SCR method are better than those of the MND SCV/SCR method since the $\Delta w$ values are smaller, and the correspondence of the total PSD to the PSD of components is more clearly visible. The maximal difference between the DFT and MND PSD is observed for A-200/PS1/Envicarb in the range of narrow pores at $R<3 \mathrm{~nm}$ (Fig. $3 a$ ). Similar but smaller differences are observed for other systems: the DFT PSD for narrow pores shift toward smaller pore sizes in comparison to the MND PSD, and the opposite result is for mesopores. These results could be explained by a stronger sensitivity of the DFT method to the presence of carbon deposits on a silica surface. For example, this deposition results in a predominant contribution of the carbon phase in the $c_{\mathrm{j}}$ weight constants up to 76-91 \% (DFT) vs. 54-64 \% (MND) for systems with soft PS1. Additionally, the DFT method provides smaller model deviations than MND (Table $1, \Delta w$ ) with the average value of 0.115 (DFT) vs. 0.236 (MND) for the ternary systems. However, the difference in the average $\Delta w$ values is smaller for the binary systems with 0.123 (DFT) vs. 0.190 (MND).
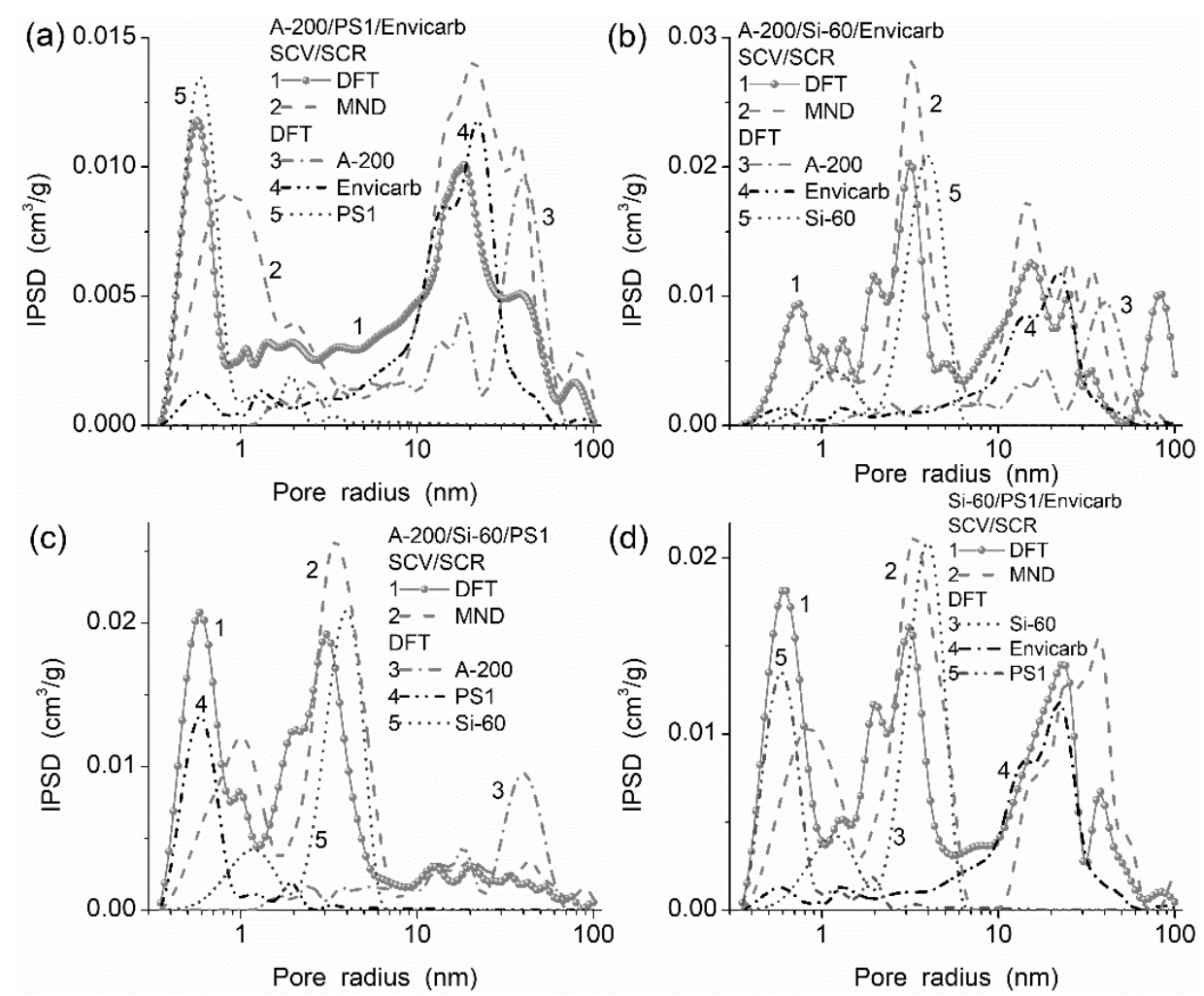

Fig. 3. Incremental PSD for ternary (DFT and MND SCV/SCR PSD) and individual (DFT, multiplied by 0.333) systems (a) A-200, PS1 and Envicarb, (b) A-200, Si-60 and Envicarb, (c) A-200, Si-60 and PS1, (d) Si-60, PS1 and Envicarb

\section{CONCLUSION}

The model with slit-shaped and cylindrical pores and voids between spherical particles (SCV) with the DFT method and self-consistent regularization (SCR) procedure was applied to different binary and ternary adsorbents composed of activated carbon, carbon black, silica gel, and fumed silica mixed in the equal weight parts. The $\mathrm{SCV} / \mathrm{SCR}$ approach based on the DFT method is effective to analyze the pore size distributions of complex materials and textural changes in the composites in comparison with the corresponding individual materials. Additionally, changes in the textural characteristics of the materials during their preparation or treatments, e.g. decomposition of one component and deposition of its fragments onto another component, pore blocking, changes in the particle morphology and texture, etc., can be analyzed in detail using the described approach. The developed DFT SCV/SCR method gives smaller deviations from 
the models than the MND SCV/SCR method developed previously [43].

\section{ACKNOWLEDGEMENTS}

The author is grateful Prof. R. Leboda, Dr. J. Skubiszewska-Zięba, Dr. B. Charmas (MCSU,
Lublin, Poland), and Dr. O.P. Kozynchenko (MAST Carbon International Ltd.) for some samples and recording nitrogen adsorptiondesorption isotherms.

\title{
Структурна характеризація складних адсорбентів в рамках теорії функціоналу густини та процедури самоузгодженої регуляризації
}

\author{
В.М. Гунько \\ Інститут хімії поверхні ім. О.О. Чуйка Національної академії наук України \\ вул. Генерала Наумова, 17, Київ,03164, Україна, vlad_gunko@ukr.net
}

\begin{abstract}
Високодисперсні та пористі комплексні та гібридні матеріали і нанокомпозити, які характеризуються наявністю кількох фаз, неоднорідною морфологією частинок та складною топологією пор різної форми, широко використовують в різних технологіях в індустрії та медицині. Точне визначення їхніх текстурних характеристик є важливим з практичної точки зору, оскільки иі характеристики відіграють важливу роль практично у всіх застосуваннях иүих матеріалів. Мета роботи: для вирішення иієї задачі було розроблено процедуру самоузгодженої регуляризаиії (SCR), щчо використовується для рімення інтегральних адсорбційних рівнянь, щзо описують адсорбиію у складних порах на основі моделі щзілинних та ичліндричних пор та проміжок між сферичними наночастинками, щзо утворюють випадкові агрегати (SCV модель), для двох-чи три-компонентних систем, щуо включають активоване вугілля, сажу, силікагель та нанокремнезем. Цей підхід було розроблено на основі методу теорії функціоналу густини (DFT). Розподіли пор за розмірами (PSD), розраховані методом DFT SCVISCR, було порівняно з PSD, розрахованими з використанням модифікованого рівняння БЕT та рівняння Кельвіна (MND метод) та SCV/SCR процедури, який було розроблено раніше. Метод DFT SCV/SCR пращює краще, оскільки він дає меншу похибку моделі для усіх бінарних та потрійних систем та краще відповідає PSD компонентів, щзо входять до композитів. Метод DFT SCV/SCR може бути використано для вивчення текстурних (структурно-адсорбційних) характеристик різних комплексних та гібридних матеріалів. Треба зазначити, щео PSD таких складних адсорбентів важко розраховувати $з$ використанням стандартних наближень, які використовують у програмному забезпеченні різних фірм, які виробляють адсорбиійне обладнання, оскільки є обмеження на типи матеріалів (зазвичай в одній моделі один) та відсутність SCR прочедури.
\end{abstract}

Ключові слова: комплексні адсорбенти, розподіл пор за розмірами, текстурні характеристики, бінарні суміші, потрійні суміші, теорії функиіоналу густини з самоузгодженою регуляризацією

\section{Структурная характеризация сложных адсорбентов в рамках теории функционала плотности и процедуры самосогласованной регуляризации}

\section{В.М. Гунько}

Институт химии поверхности им. А.А. Чуйко Национальной академии наук Украиньь ул. Генерала Наумова, 17, Киев, 03164, Украина, vlad_gunko@ukr.net

\footnotetext{
Высокодисперсные $u$ пористые комплексные $и$ гибридные материаль $и$ нанокомпозиты, характеризующиеся наличием нескольких фаз, неоднородной морфологией частии и сложной топологией пор разной формы, широко используют в разных технологиях в индустрии и медицине. Точное определение их текстурных характеристик важно с практической точки зрения, поскольку эти характеристики играют важную роль практически во всех применениях этих материалов. Цель работь: для решения этой задачи
} 
была разработана процедура самосогласованной регуляризаџии (SCR), которая используется для решения интегральных адсорбиионных уравнений, которые описывают адсорбцию в сложных порах на основе модели щелевых и иялиндрических пор и промежутков между сферическими наночастицами, которые образуют случайные агрегаты (SCV модель), для двух- и трехкомпонентных систем, включаюших активированный уголь, сажу, силикагель и нанокремнезем. Этот подход был разработан на основе метода теории функционала плотности (DFT). Распределения пор по размерам (PSD), рассчитанные методом DFT SCV/SCR, были сопоставлены с PSD, рассчитанными для тех же материалов с использованием модифицированного уравнения БЭТ и уравнения Кельвина (MND метод) и SCV/SCR процедуры, разработанной ранее. Метод DFT SCV/SCR работает лучше, поскольку он дает меньшие ошибки модели для всех бинарных и тройных систем и лучше соответствует PSD компонентов, входящих в композиты. Метод DFT SCV/SCR может быть использован для изучения текстурных (структурно-адсорбционных) характеристик разных комплексных и гибридных материалов. Следует отметить, что PSD таких сложных адсорбентов сложно рассчитывать с использованием стандартных приближений, используемых в программном обеспечении разных фирм, изготовляющих адсорбционное оборудование, поскольку есть ограничение на типь материалов (в оной модели - один) и отсутствие SCR процедуры.

Ключевые слова: комплексные адсорбенты, распределение пор по размерам, текстурные характеристики, бинарные смеси, тройные смеси, теория функционала плотности с самосогласованной регуляризачией

\section{REFERENCES}

1. Tarazona P., Marconi U.M.B., Evans R. Phase equilibria of fluid interfaces and confined fluids - non-local versus local density functionals. Mol. Phys. 1987. 60(3): 573.

2. Lastoskie C., Gubbins K.E., Quirke N. Pore size distribution analysis of microporous carbons: a density functional theory approach. J. Phys. Chem. 1993. 97(18): 4786.

3. Olivier J.P. Modeling physical adsorption on porous and nonporous solids using density functional theory. J. Porous Mater. 1995. 2: 9.

4. Olivier J.P. Improving the models used for calculating the size distribution of micropore volume of activated carbons from adsorption data. Carbon. 1998. 36(10): 1469.

5. Olivier J.P., Occelli M.L. Surface area and microporosity of a pillared interlayered clay (pilc) from a hybrid density functional theory (DFT) method. J. Phys. Chem. B. 2001. 105(3): 5358.

6. Occelli M.L., Olivier J.P., Perdigon-Melon J.A., Auroux A. Surface area, pore volume distribution, and acidity in mesoporous expanded clay catalysts from hybrid density functional theory (DFT) and adsorption microcalorimetry methods. Langmuir. 2002. 18(25): 9816.

7. Occelli M.L., Olivier J.P., Petre A., Auroux A. Determination of pore size distribution, surface area, and acidity in fluid cracking catalysts (fccs) from nonlocal density functional theoretical models of adsorption and from microcalorimetry methods. J. Phys. Chem. B. 2003. 107(17): 4128.

8. Occelli M.L., Olivier J.P., Auroux A., Kalwei M., Eckert H. Basicity and porosity of a calcined hydrotalcite-type material from nitrogen porosimetry and adsorption microcalorimetry methods. Chem. Mater. 2003. 15(22): 4231.

9. Jagiello J., Olivier J.P. A simple two-dimensional NLDFT model of gas adsorption in finite carbon pores. Application to pore structure analysis. J. Phys. Chem. C. 2009. 113(45): 19382.

10. Maddox M.W., Olivier J.P., Gubbins K.E. Characterization of MCM-41 using molecular simulation. Heterogeneity effects. Langmuir. 1997. 13(6): 1737.

11. Jaroniec M., Kruk M., Olivier J.P., Koch S. A new method for the accurate pore size analysis of MCM-41 and other silica based mesoporous materials. In: Proceedings of the Fifth International Symposium on the Characterization of Porous Solids, COPS-V. V. 128. (Studies in Surface Science and Catalysis, Elsevier, 2000).

12. Thommes M. Physical adsorption characterization of nanoporous materials. Chem. Ing. Tech. 2010. 82(7): 1059.

13. Gor G.Y., Thommes M., Cychosz K.A, Neimark A.V. Quenched solid density functional theory method for characterization of mesoporous carbons by nitrogen adsorption. Carbon. 2012. 50(4): 1583.

14. Neimark A.V., Lin Y., Ravikovitch P.I., Thommes M. Quenched solid density functional theory and pore size analysis of micro-mesoporous carbons. Carbon. 2009. 47(7): 1617.

15. Ravikovitch P.I., Neimark A.V. Characterization of nanoporous materials from adsorption and desorption isotherms. Colloid Surf. A. 2001. 187-188: 11. 
16. Ravikovitch P.I., Neimark A.V. Density functional theory model of adsorption on amorphous and microporous silica materials. Langmuir. 2006. 22(26): 11171.

17. Landers J., Gor G.Y., Neimark. A.V. Density functional theory methods for characterization of porous materials. Colloids Surf. A. 2013. 437: 3.

18. Barrett E.P., Yoyner L.G., Halenda P.P. The determination of pore volume and area distributions in porous substances. 1. Computations from nitrogen isotherms. J. Am. Chem. Soc. 1951. 73(1): 373.

19. Marsh H., Rodríguez-Reinoso F. Activated Carbon. (London: Elsevier, 2006).

20. Ustinov E.A., Do D.D., Fenelonov V.B. Modeling of heterogeneous surfaces and characterization of porous materials by extending density functional theory for the case of amorphous solids. Appl. Surf. Sci. 2007. 253(13): 5610 .

21. Ustinov E.A., Do D.D., Fenelonov V.B. Pore size distribution analysis of activated carbons. Application of density functional theory using nongraphitized carbon black as a reference system. Carbon. 2006. 44(4): 653.

22. Nguyen T.X., Bhatia S.K. Characterization of accessible and inaccessible pores in microporous carbons by a combination of adsorption and small angle neutron scattering. Carbon. 2012. 50(8): 3045.

23. Davies G.M., Seaton N.A. Characterization of the internal structure of microporous carbons using pore size. Carbon. 1998. 36(10): 1473.

24. Cimino R., Cychosz K.A., Thommes M., Neimark A.V. Experimental and theoretical studies of scanning adsorption-desorption isotherms. Colloids Surf. A. 2013. 437: 76.

25. Rouquerol J., Baron G.V., Denoyel R., Giesche H., Groen J., Klobes P., Levitz P., Neimark A.V., Rigby S., Skudas R., Sing K., Thommes M., Unger K. The characterization of macroporous solids: An overview of the methodology. Microporous Mesoporous Mater. 2012. 154: 2.

26. Ustinov E.A., Staudt R., Do D.D., Herbst A., Harting P. Multicomponent adsorption on activated carbons under supercritical conditions. J. Colloid Interface Sci. 2004. 275(2): 376.

27. Shahrak M.N., Shahsavand A., Okhovat A. Robust PSD determination of micro and meso-pore adsorbents via novel modified U curve method. Chem. Eng. Res. Des. 2013. 91(1): 51.

28. Shahsav A., Shahrak M.N. Direct pore size distribution estimation of heterogeneous nano-structured solid adsorbents from condensation data. Condensation with no prior adsorption. Colloids Surf. A. 2011. 378(1-3): 1.

29. Meng X., Foston M., Leisen J., DeMartini J., Wyman C.E., Ragauskas A.J. Determination of porosity of lignocellulosic biomass before and after pretreatment by using Simons' stain and NMR techniques. Bioresour. Technol. 2013. 144: 367.

30. Ghashghaee M., Karimzadeh R. Evolutionary model for computation of pore-size distribution in microporous solids of cylindrical pore structure. Microporous Mesoporous Mater. 2011. 138(1-3): 22.

31. KuilaU., Prasad M. Specific surface area and pore-size distribution in clays and shales. Geophys. Prospect. 2013. 61(2): 341.

32. Jorge M., Seaton N.A. Predicting adsorption of water/organic mixtures using molecular simulation. AIChE J. 2003. 49(8): 2059.

33. Gusev Yu., O'Brien J.A., Seaton N.A. A self-consistent method for characterization of activated carbons using supercritical adsorption and grand canonical Monte Carlo simulations. Langmuir. 1997. 13(10): 2815.

34. Thomson K.T., Gubbins K.E. Modeling structural morphology of microporous carbons by reverse Monte Carlo. Langmuir. 2000. 16(13): 5761.

35. Gun'ko V.M., Leboda R., Turov V.V., Charmas B., Skubiszewska-Zięba J. Structural and energetic heterogeneities of hybrid carbon-mineral adsorbents. Appl. Surf. Sci. 2002. 191(1-4): 286.

36. Gun'ko V.M., Turov V.V., Leboda R. Structure-adsorption characteristics of carbon-oxide materials. Theor. Exp. Chem. 2002. 38(4): 199.

37. Gun'ko V.M., Leboda R., Skubiszewska-Zięba J. Heating effects on morphological and textural characteristics of individual and composite nanooxides. Adsorption. 2009. 15(2): 89.

38. Gun'ko V.M., Zarko V.I., Turov V.V., Oranska O.I., Goncharuk E.V., Nychiporuk Y.M., Pakhlov E.M., Yurchenko G.R., Leboda R., Skubiszewska-Zięba J., Osovskii V.D., Ptushinskii Y.G., Derzhypolskyi A.G., Melenevsky D.A., Blitz J.P. Morphological and structural features of individual and composite nanooxides with alumina, silica, and titania in powders and aqueous suspensions. Powder Technol. 2009. 195(3): 245.

39. Gun'ko V.M., Meikle S.T., Kozynchenko O.P., Tennison S.R., Ehrburger-Dolle F., Morfin I., Mikhalovsky S.V. Comparative characterization of carbon and polymer adsorbents by SAXS and nitrogen adsorption methods. J. Phys. Chem. C. 2011. 115(21): 10727.

40. Gun'ko V.M., ZaulychnyyYa.V., Ilkiv B.I., Zarko V.I., Nychiporuk Yu.M., Ptushinskii Yu.G., Pakhlov E.M., Leboda R., Skubiszewska-Zięba J. Textural and electronic characteristics of mechanochemically activated composites with nanosilica and activated carbon. Appl. Surf. Sci. 2011. 258(3): 1115. 
41. Gun'ko V.M., Kozynchenko O.P., Tennison S.R., Leboda R., Skubiszewska-Zięba J., Mikhalovsky S.V. Comparative study of nanopores in activated carbons by HRTEM and adsorption methods. Carbon. 2012. 50(9): 3146.

42. Gun'ko V.M., Turov V.V. Nuclear Magnetic Resonance Studies of Interfacial Phenomena. (Boca Raton: CRC Press, 2013).

43. Gun'ko V.M. Composite materials: textural characteristics. Appl. Surf. Sci.2014. 307: 444.

44. Gun'ko V.M. Various methods to describe the morphological and textural characteristics of various materials. Him. Fiz. Tehnol. Poverhni. 2018. 9(4): 317.

45. Gun'ko V.M. Theoretical analysis of adsorption of various compounds onto hydrophilic and hydrophobic silicas compared to activated carbons. Him. Fiz. Tehnol. Poverhni. 2019. 10(4): 340.

46. Nguyen C., Do D.D. A new method for the characterization of porous materials. Langmuir. 1999. 15(10): 3608.

47. Nguyen C., Do D.D. Effects of probing vapors and temperature on the characterization of micro-mesopore size distribution of carbonaceous materials. Langmuir. 2000. 16(18): 7218.

48. Gun'ko V.M., Do D.D. Characterization of pore structure of carbon adsorbents using regularization procedure. Colloids Surf. A. 2001. 193(1-3): 71.

49. Sternik D., Galaburda M., Bogatyrov V.M., Gun'ko V.M. Influence of the synthesis method on the structural characteristics of novel hybrid adsorbents based on bentonite. J. Colloid Interface Sci. 2019. 3(1): 18.

50. Gun'ko V.M. Nano/meso/macroporous materials characterization affected by experimental conditions and features of the used methods. Him. Fiz. Tehnol. Poverhni. 2020. 11(1): 5.

51. Protsak I., Gun'ko V.M., Henderson I.M., Pakhlov E.M., Sternik D., Le Z. Nanostructured amorphous silicas hydrophobized by various pathways. ACS Omega. 2019. 4(9): 13863.

52. Brunauer S., Emmett P.H., Teller E. Adsorption of gases in multimolecular layers. J. Am. Chem. Soc. 1938. 60(2): 309.

53. Gregg S.J., Sing K.S.W. Adsorption, Surface Area and Porosity. Second Ed. (London: Academic Press, 1982).

54. Ravikovitch P.I., Haller G.L., Neimark A.V. Density functional theory model for calculating pore size distributions. Pore structure of nanoporous catalysts. Adv. Colloid Interface Sci. 1998. 76-77: 203.

55. Do D.D., Nguyen C., Do H.D. Characterization of micro-mesoporous carbon media. Colloids Surf. A. 2001. 187-188: 51.

56. Gun'ko V.M., Turov V.V., Leboda R., Zarko V.I., Skubiszewska-Zięba J., Charmas B. Adsorption, NMR and thermally stimulated depolarization current methods for comparative analysis of heterogeneous solid and soft materials. Langmuir. 2007. 23(6): 3184.

57. Platzer B., Maurer G. Application of a generalized Bender equation of state to the description of vapour-liquid in binary systems. Fluid Phase Equilib. 1993. 84: 79.

58. Provencher S.W. A constrained regularization method for inverting data represented by linear algebraic or integral equations. Comput. Phys. Commun. 1982. 27(3): 213.

59. Gun'ko V.M., Mikhalovsky S.V. Evaluation of slitlike porosity of carbon adsorbents. Carbon. 2004. $42(4)$ : 843. 